\title{
Productive Ageing Regimes in Europe: Welfare State Typologies Explaining Elderly Europeans' Participation in Paid and Unpaid Work
}

\author{
Susanne Strauss ${ }^{1} \cdot$ Kathrin Trommer $^{1}$
}

\begin{abstract}
The share of elderly in European populations has grown and these elderly are living healthier and longer lives. Policy makers in Europe have accordingly identified an increasing potential for this group to participate in different forms of paid and unpaid activities. In order to systematize European elderly's productive activities, the article proceeds in two steps: First, it reviews previous research on country differences in European elderly's participation in employment, informal care for elderly relatives and volunteering in clubs and associations. Based on data from the European Social Survey (ESS), in a second step we assess the analytical potential of different welfare state typologies, using linear regression models. Our analyses measure to what extent the typologies, which were developed for the general population, are suitable for explaining country differences in the elderly's participation in paid and unpaid productive activities. We conclude that the north-south gradient, which we observe for all three types of productive ageing activities of elderly Europeans is mainly related to the role which welfare states attribute to the family. Welfare states with a high degree of defamilialisation fare best in encouraging their elderly men and women to participate in all types of paid and unpaid productive activities.
\end{abstract}

Keywords Aging $\cdot$ Employment $\cdot$ Europe $\cdot$ Family $\cdot$ Social capital $\cdot$ Welfare state

Susanne Strauss

susanne.strauss@uni-konstanz.de

1 Department of History and Sociology, University of Konstanz, PO Box 26, 78457 Konstanz, Germany 


\section{Introduction}

In times of population ageing, political discussions as well as debates within the social sciences tend to focus on difficulties arising from this demographic development (for an overview, see Erlinghagen 2008). At the same time however, another strand of growing importance in social sciences literature stresses the chances related to the growing group of "young elderly", especially their productive potential. Research is not always unanonimous about what is to be understood as productive activities though (MorrowHowel et al. 2001; Erlinghagen and Hank 2008). One attempt to define productive activities of the elderly is that it comprises any activity which is either paid or could potentially be paid. Most authors agree that this includes employment, informal caregiving and volunteering in organisations (O'Reilly and Caro 1995; Caro 2008). This discussion has also been taken up by policy advisors who are interested in supporting elderly's productive potential. In light of this, the statistical division of the United National Economic Commission for Europe (UNECE) together with the European Commission (EC) and an expert group developed an Active Ageing Index (AAI) (Zaidi et al. 2013) which measures elderly's potential for active and healthy ageing in four domains: (1) employment, (2) participation in society (including voluntary activities, care of children and grandchildren, care of older adults and political participation), (3) independent, healthy and secure living and (4) capacity and enabling environment for active ageing. ${ }^{1}$ The drawback of this approach in our opinion is that it is difficult to interpret the index since it combines a variety of behavioural and institutional aspects. Often the combination of indicators into one index disguises that countries perform very differently in specific areas: Thus, the high values of Italy and Sweden on the participation in society index are based on participation in care work in the case of Italy and volunteering in the case of Sweden. We instead consider it more insightful to analyse these different paid and unpaid activities separately and to systematically compare the results. The aim of our article however is different: We want to give an overview on welfare state typologies regarding different forms of paid and unpaid work and test in how far these typologies, which were developed for the general population, are suitable for a theoretical systematisation of productive ageing regimes in Europe.

\section{How Productive are Europe's Elderly?}

In order to have a better understanding of the empirical phenomenon which is to be explained, we start by giving an overview on existing research about European elderly's productive activities in the areas of employment, informal caregiving and volunteering.

\section{Employment of the Elderly in Europe}

While employment rates of men aged 50 to 55 are rather high throughout Europe (between 71\% in Spain and 93\% in Iceland, OECD 2014), there are significant differences regarding men above that age among countries. In 2014, the employment

\footnotetext{
${ }^{1} \mathrm{http}: / /$ www1.unece.org/stat/platform/display/AAI/Active+Ageing+Index+Home
} 
population ratio for men aged between 60 and 64 varies substantially between countries. On top of the range we find Iceland (85\%), Sweden (69\%), Norway (69\%) and Switzerland $(68 \%)$. On the other side we observe very low levels in Slovenia $(24 \%)$, France (25\%) and Hungary (27\%) (OECD 2014).

Regarding female employment rates among the elderly, differences by country are larger among women aged 50 to 55, than among their male counterparts and increase further in higher age groups (OECD 2014). Especially in Mediterranean countries such as Greece, Spain and Italy, employment rates of women aged 50 to 54 are very low (46-57\%). In the same age group in East European countries employment rates are much higher, from Poland (70\%) to Estonia (84\%) and the Czech Republic (86\%). It is also high in Iceland (85\%), Switzerland (84\%) and Scandinavian countries, like Finland, Denmark, Norway and Sweden (80-82\%). We observe a similar trend for women aged 55 to 59, but on a lower level (OECD 2014).

\section{Informal Care Work of the Elderly in Europe}

Informal care is a widespread activity among Europeans aged 50 or older: Based on data from the Survey of Health, Ageing and Retirement in Europe (SHARE) 2009, Haberkern et al. (2012) conclude that between 38 and $66 \%$ of this age group provide informal support to family members and friends. While there is plenty of comparative research addressing differences in child care provision among countries (Bettio and Plantenga 2004; Crompton and Lyonette 2006; Mahon 2002; Szelewa and Polakowski 2008), informal care for elderly relatives has been in the focus of comparative welfare state research to a much lesser extent. On the individual level, several factors have been identified which increase the likelihood of continuous informal caregiving, such as geographical proximity, lack of alternative caregivers and female gender (Szinovacz and Davey 2008). Although women and men are both involved in elderly care of their parents and parents-in-law, the non-employed partner (usually the woman) is more involved than the employed partner (Henz 2009). The finding that adult daughters spend more time assisting their parents than sons do is partly explained by women's inferior employment status, especially lower wages (Sarkisian and Gerstel 2004). From previous comparative research we know that informal care of children for their parents is more widespread in Southern Europe due to the lack of welfare support, while in Northern Europe adult children provide more additional help (with household work or authorities) (Brandt et al. 2009). One explanation for this north-south gradient is that women's employment is negatively associated with informal elder-care (Kotsadam 2011).

\section{Voluntary Engagement of the Elderly in Europe}

Beyond the realm of market and family, a third important form of productive ageing concerns voluntary engagement. This term includes activities which are voluntary and unpaid, provided to people outside the family, organised by a club (or stable group) for a certain period of time (for an overview on the term and how it is distinguished from other activities, see Ehrhardt 2009). On the individual level, older volunteers are more likely to have a high socio-economic status, to be married, have a religious affiliation, be in paid employment, have a large social network and a history of volunteering (Erlinghagen and Hank 2008). Moreover, it has been shown for the German case that 
volunteering is relatively stable over the life course, although life course events in the family domain have a (limited) effect on the frequency of volunteering (Lancee and Radl 2014). There are comparatively few studies analysing country differences in voluntary work. Those which do exist show important variations regarding voluntary engagement in the general population (Salamon and Sokolowski 2004) as well as among the elderly (Hank and Erlinghagen 2005). As to those aged older than 50, previous research finds a north-south-gradient with much higher involvement rates in Northern Europe (Netherlands 21\%, Denmark and Sweden 17\%) than in Southern European countries (Italy 7\%, Greece and Spain 2-3\%) (Hank and Erlinghagen 2010). These country differences are attributed to greater political and religious freedom on the one hand and better provision of welfare services in North European countries on the other (Hank 2011).

We thus see that there is much variation regarding all forms of productive ageing in European countries. A common trend concerning employment as well as informal care and volunteering for both genders is a north-south gradient in participation, i.e. that elderly Scandinavians are more likely to participate in any of the observed productive activities as compared to their South European counterparts.

In the remainder of this article we will present a range of theoretical approaches suggesting country typologies and test their suitability for explaining differences in various productive ageing activities. At the end of the article we will discuss to what extent it is possible to combine these area-specific typologies in order to speak more generally about productive ageing regimes in Europe.

\section{Explaining Differences in Employment of Europeans Aged 50 and Older}

In his well-known classification of welfare states, Esping-Andersen (1990) differentiates between three types of welfare states: the social democratic, the conservative and the liberal welfare state regime. In his later analysis, he additionally differentiates between familiarised and de-familiarised welfare states which enables the identification of the additional type of Mediterranean welfare regimes (Esping-Andersen 1999). The author's main argument is that countries differ in their degree of de-commodification, i.e. the degree to which the welfare state provides means to survive independently of one's labour market participation. Family is mainly considered in its role of providing welfare that the state does not deliver.

Other welfare state typologies have criticised that Esping-Andersen's (1990, 1999) classical approach focuses mainly on paid work, neglecting the strong importance of unpaid work in women's life courses. Drawing on this criticism, a number of gender sensitive welfare typologies have been developed. While some of them are closely related to Esping-Andersen's (1990, 1999) classification of welfare states (e.g. Morel 2007; Pfau-Effinger 2005), others derive completely different typologies (Lewis and Ostner 1994).

A more recent approach, which is based on this criticism of disregarding women's situation, is Pfau-Effinger's (2005) typology of welfare states which focuses on "different cultural models about the family and the way it is related with gender and care" (Pfau-Effinger 2005). Her typology comprises (1) a male breadwinner/housewife model, (2) a male breadwinner/female part-time carer model, (3) a dual breadwinner/ 
external childcare model, and (4) a dual breadwinner/dual carer model. Pfau-Effinger argues that in some countries, informal care can play an important role - despite a modernised cultural concept of the family and of gender equality.

From our perspective, Pfau-Effinger's approach is a valuable alternative to EspingAndersen's typology of labour market participation. Pfau-Effinger's typology is designed to describe the labour market participation of parents with young children. She does not refer to the working situation of the elderly. We argue however that it might still be fruitful for explaining the situation of the elderly due to a path-dependency over women's working lives: People who suspend their employment to care for children are also more likely to leave the labour market if, for example, an older family member needs care. This path-dependency in life courses has been discussed under the heading of cumulative advantages/disadvantages (DiPrete and Eirich 2006).

In order to test which of the available typologies is empirically best suited for examining different forms of productive ageing, we used European Social Survey $(\mathrm{ESS})^{2}$ data. The ESS is a representative survey covering 30 countries, mainly situated in Europe. In each country, randomly selected individuals aged 15 or older who live in private households were interviewed. For our purpose of investigating productive ageing, we reduced the sample to those aged 50 to 75 .

We created country-specific weighted means of relevant indicators. For the typology of paid work we calculated the share of people aged 50 to 75 who are involved in paid work. We then calculated separate regressions for each typology with those means as dependant variables and the country clusters as independent variables.

In order to test if Pfau-Effinger's typology depicts the labour market participation of elderly men and especially women in European countries better than EspingAndersen's classical typology, we compared the explanatory potential of the two typologies. In the second wave of the ESS, people were asked what they had been doing over the past 7 days. One of the options they could choose from a show card was 'paid work'. ${ }^{3}$ We created a country-specific mean (using post-stratification-weights) of people aged between 50 and 75 doing paid work. In our first regression we calculated how well these country-specific means can be predicted by adding dummies for country clusters according to Esping-Andersen's typology, in the second one we did the same with country clusters from Pfau-Effinger's typology.

Information about labour market participation is available for 24 European countries in the second ESS wave. ${ }^{4}$ Both authors did not consider all the countries from which we have available data in the ESS. To evaluate the adequacy of the typologies on active ageing in Europe as broadly as possible, we expand those typologies to include additional European countries. In Table 1 those countries we added can be identified through italic script.

As Mills and Blossfeld (2005) suggested, we added a post-socialist regime type to Esping-Andersen's typology, containing those countries which experienced a socialist regime for a large part of the twentieth century. Additionally, we included Iceland

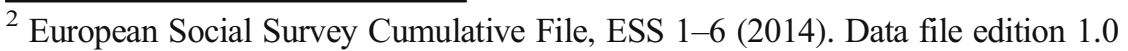

${ }^{3}$ Paid work comprises employment, self-employment or working for a family business. It also includes respondents who are only temporarily not working.

${ }^{4}$ We find no substantial difference in the outcome if we use data from wave 6 (2012). To make the results comparable to our analyses on informal caring, we based our analysis on the second ESS wave.
} 
Table 1 Classification of welfare typologies regarding elderly's employment

\begin{tabular}{|c|c|c|}
\hline Author & Classification & Country \\
\hline \multirow{5}{*}{$\begin{array}{l}\text { Esping- } \\
\text { Andersen } \\
(1990,1999)\end{array}$} & (1) social-democratic & $\begin{array}{l}\text { Denmark (51), Finland (50), Netherlands (57), } \\
\text { Norway (65), Sweden (61), } \\
\text { Iceland (80) }\end{array}$ \\
\hline & (2) conservative & $\begin{array}{l}\text { Austria (51), Belgium (33), France (39), Germany } \\
\text { (43), Switzerland (63), } \\
\text { Luxembourg (41) }\end{array}$ \\
\hline & (3) liberal & $\begin{array}{l}\text { Ireland (61), } \\
\text { Great Britain (49) }\end{array}$ \\
\hline & (4) mediterranean & Greece (41), Portugal (43), Spain (49) \\
\hline & (5) post-socialistic & $\begin{array}{l}\text { Czech Republic (43), Estonia (54), Hungary (40), } \\
\text { Poland (28), Slovenia (51), Slovakia (48) }\end{array}$ \\
\hline \multirow{4}{*}{$\begin{array}{l}\text { Pfau- } \\
\text { Effinger } \\
(\mathbf{2 0 0 5 )}\end{array}$} & $\begin{array}{l}\text { (1) housewife model of the male } \\
\text { breadwinner family }\end{array}$ & $\begin{array}{l}\text { Greece (41), Hungary (40), Ireland (61), Luxembourg } \\
\text { (41), Spain (49) }\end{array}$ \\
\hline & $\begin{array}{l}\text { (2) The male breadwinner/ female part- } \\
\text { time carer model }\end{array}$ & $\begin{array}{l}\text { Great Britain (49), Germany (43) } \\
\text { Austria (51), Belgium (33), Switzerland (63) }\end{array}$ \\
\hline & (3) dual breadwinner / external care model & $\begin{array}{l}\text { Denmark (51), Finland (50), France (39), Sweden } \\
(61), \\
\text { Czech Republic (43), Estonia (54), Iceland (80), } \\
\text { Poland (28), Portugal (43), Slovenia (51), Slovakia } \\
(48)\end{array}$ \\
\hline & (4) dual breadwinner / dual carer model & Netherlands (57), Norway (65) \\
\hline
\end{tabular}

Remark: Numbers in parentheses indicate the employment rate of men and women aged 50 to 75 , for a gender separated overview on the share of elderly workers in country see Table A1 in the online appendix

${ }^{a}$ Pfau-Effinger only refers to Westen Germany. Since the other typology does not differentiate between the two parts of the country, we also include both East and West Germany

(Olafsdottir 2007), Luxembourg (Kerschen 2009) and Great Britain (Mitton 2009) to those regime types respectively best suited, according to national studies.

In Pfau-Effinger's (2005) typology, the first group contains countries where being a housewife is common for women. We therefore included those countries which have, according to OECD data (see supplement Fig. 1), rather low female labour force participation such as Italy, Ireland or Greece. In the second group (male breadwinner/ female part-time carer) we added countries where women have medium to high labour force participation but often work part-time only, like Switzerland or Germany. Finally, we added those countries with high labour force participation and low part-time work to the third group, which contains dual breadwinner families.

Pfau-Effinger suggests a forth group, containing Norway and the Netherlands as countries with a dual breadwinner and dual carer model, where care is less externalised but both parents reduce work to do caring tasks. Based on OECD data, we can confirm that these two countries have the highest rate for male part-time work, but on a very low scale (Netherlands just over $6 \%$ of all working men; Norway 5.7\%) with little difference to other countries (see supplement Fig. 2). We therefore leave them in a separate group as Pfau-Effinger suggests but do not include further countries in this group.

To evaluate the adequacy of the two typologies, we use linear regressions with country-specific employment rates as dependent variables and country clusters as 
independent variables. As Table 2 shows, Esping-Andersen's typology describes the labour market participation of elderly men and women throughout Europe better than Pfau-Effinger's typology does.

Akaike's information criterion (AIC) is clearly lower in Esping-Andersen's typology (men -37.26/ women -31.05) as in Pfau-Effinger's typology (men -30.06/women $-18.96)$. Additionally, the adjusted $\mathrm{R}^{2}$ points in the same direction, being larger for men (0.27 compare to -0.03$)$ as well as for women (0.46 compare to 0.06$)$ for EspingAndersen's typology.

Pfau-Effinger did not intend to present a typology for elderly people. As mentioned above, we expected, that - by mechanisms of cumulative disadvantages - especially for women the situation of mothers with young children in a country might be comparable to the situation of elderly women. Looking at the data, this does not seem to be the case. ${ }^{5}$ This means that Esping-Andersen's typology still seems to be the best available typology for accounting for country differences between elderly's labour force participation. This suggests that the mechanism of de-commodification as introduced by Esping-Andersen in combination with his later differentiation between familiarised and de-familiarised welfare states seems to captures differences in elderly Europeans' labour market participation better than Pfau-Effinger's focus on cultural models of informal care, resulting in different couple strategies. A possible reason is the focus on cultural models of care leading to rather diverse country clusters regarding welfare provision: Thus, although Germany and Great Britain both have a male breadwinner/ female part-time carer model, the German welfare state is much more generous than the British one. Related to this difference, part-time employment is generally also much more need-driven and precarious in Great Britain than in Germany. This aspect seems to be captured better by Esping-Andersen's dimension of de-commodification.

\section{Caring Typologies in Europe}

A number of typologies have also been developed to explain differences in informal caring activities. Again, they are meant to describe differences in the general population. The aim of our analysis is to test which of these classifications best describes differences in caring activities of people aged 50 to 75 .

Bettio and Plantenga (2004) developed a care typology which focuses on the provision of care for both children and elderly people. We only refer to those parts dealing with elderly care since our interest is in the productivity of people aged 50 or older, which are rarely involved in care for their own children. The starting point for Bettio and Plantenga's typology is that "European countries differ widely in the extent to which they rely on informal care services" and also on how many elderly people are living in care institutions rather than their private homes (Bettio and Plantenga 2004: 86). Bettio and Plantenga identify five care models for Europe. The first group (1) is composed of countries which attribute all caring responsibility to the family. This is the case in many European

\footnotetext{
${ }^{5}$ Moreover, Pfau-Effinger's cultural approach would ideally be operationalized by using an indicator referring to people's opinion on working women (or mothers). The ESS 2004 does not include indicators which capture whether people think that family is the "best" form of care and available items which touch upon the issue do not cover at all care for elderly people.
} 
Table 2 Explanatory power of welfare typologies regarding elderly's employment (age 50-75)

\begin{tabular}{llll}
\hline & & Esping-Andersen & Pfau-Effinger \\
\hline \multirow{4}{*}{ Men } & N & 23 & 23 \\
& Groups & 5 & 4 \\
& R2 & 0.41 & 0.11 \\
& Adj. R2 & 0.27 & -0.03 \\
\multirow{3}{*}{ Women } & AIC & -37.26 & -30.06 \\
& BIC & -31.58 & -25.52 \\
& R2 & 0.56 & 0.18 \\
& Adj. R2 & 0.46 & 0.06 \\
& AIC & -31.05 & -18.96 \\
& BIC & -25.37 & -14.42 \\
\hline
\end{tabular}

ESS (2004), own calculations

countries such as Mediterranean countries, post-communist countries and Ireland. In these countries informal care is quite common and formal care services are underdeveloped. The second group (2) contains those countries in which informal care work still plays a substantial role, but elderly care is seen as a collective responsibility, which leads to a high supply of residential care. Examples are Great Britain, Switzerland and the Netherlands. The third group (3) contains countries in which informal care is the dominant form of care, but unlike the countries in the first group, the costs for care are compensated by collective arrangements. This is the case for Austria, Germany, and Luxembourg. In the fourth group (4), care strategies for the elderly are rather well developed, so that we find medium levels for residential care as well as for informal care, like in Belgium, France and Iceland. The last group (5) contains those countries where we find a universalistic approach. Elderly care is not seen as a responsibility of the family, so that all forms of formal care services are well developed. This is the case in Scandinavian countries, like Denmark, Finland, Norway and Sweden. Table 3 gives an overview which groups countries belong to according to the different typologies. Because the authors did not consider all countries of our available ESS data, we added missing countries according to the authors' criterions. These criterions are (1) the extent of public care provision compared to the degree of informal care provision and (2) whether there is cost compensation through the state or public insurances. ${ }^{6}$

Haberkern and Szydlik (2008) explicitly focus on elderly care in their typology and suggest to consider two dimensions of care. The first dimension observes if and to what extent people have an obligation to support their elderly family members, if necessary. The second dimension considers how much support is granted by the government either through financial means or by providing elderly homes and home care services. Haberkern and Szydlik (2008) find that within Europe those two dimensions are closely related and therefore suggest distinguishing only two care models.

\footnotetext{
${ }^{6}$ A detailed table on the classification can be found in the supplement Table 1. Added countries can be identified through italic script.
} 
Table 3 Classification of welfare typologies on caring

\begin{tabular}{|c|c|c|}
\hline Author & $\begin{array}{l}\text { Classifi- } \\
\text { cation }\end{array}$ & Country \\
\hline \multirow{5}{*}{$\begin{array}{l}\text { Bettio/ } \\
\text { Plantenga } \\
(2004)\end{array}$} & 1 & $\begin{array}{l}\text { Greece (44), Ireland (50), Portugal (35), Spain (41), } \\
\text { Czech Republic (65), Estonia (59), Hungary (63), Poland (55), Slovenia (53), Slovakia } \\
\text { (56) }\end{array}$ \\
\hline & 2 & $\begin{array}{l}\text { Great Britain (57), Netherlands (56), } \\
\text { Switzerland (57) }\end{array}$ \\
\hline & 3 & $\begin{array}{l}\text { Austria (70), Germany (60), } \\
\text { Luxembourg (50) }\end{array}$ \\
\hline & 4 & $\begin{array}{l}\text { Belgium (52), France (60), } \\
\text { Iceland (86) }\end{array}$ \\
\hline & 5 & $\begin{array}{l}\text { Denmark (61), Finland (72), Sweden (71), } \\
\text { Norway (81) }\end{array}$ \\
\hline \multirow{2}{*}{$\begin{array}{l}\text { Haberkern/ } \\
\text { Szydlik } \\
(\mathbf{2 0 0 8 )}\end{array}$} & 1 & $\begin{array}{l}\text { Austria (70), Belgium (52), France (60), Germany (60), Greece (44), Netherlands (56), } \\
\text { Spain (41), } \\
\text { Czech Republic (65), Estonia (59), Hungary (63), Ireland (50), Poland (55), Portugal } \\
\text { (35), Slovenia (53), Slovakia (56) }\end{array}$ \\
\hline & 2 & $\begin{array}{l}\text { Denmark (61), Sweden (71), Switzerland (57) } \\
\text { Finland (72), Great Britain (57), Iceland (86), Luxembourg (50), Norway (81) }\end{array}$ \\
\hline \multirow{4}{*}{$\begin{array}{l}\text { Saraceno/ } \\
\text { Keck (2010) }\end{array}$} & 1 & $\begin{array}{l}\text { Greece (44), Poland (55), Portugal (35), Slovakia (56), Spain (41), } \\
\text { Slovenia (53) }\end{array}$ \\
\hline & 2 & Czech Republic (65), Estonia (59), Germany (60), Great Britain (57), Hungary (63) \\
\hline & 3 & $\begin{array}{l}\text { Austria (70), Belgium (52), Denmark (61), France (60), Iceland (86), Luxembourg (50), } \\
\text { Netherlands (56), Norway (81), Sweden (71) }\end{array}$ \\
\hline & 4 & $\begin{array}{l}\text { Finland (72), } \\
\text { Iceland (86), Switzerland (57) }\end{array}$ \\
\hline
\end{tabular}

Remark: Numbers in parentheses indicate the share of informal caregivers among men and women aged 50 to 75 , for a gender separated overview on the share of informal caregivers in country see Table A1 in the online appendix

The first model (1) is a family-based model, in which comprehensive family obligations are associated with only rudimentary availability of professional care and intergenerational family care being the norm. This group comprises Austria, Belgium, Czech Republic, Estonia, France, Germany, Greece, Hungary, Ireland, Italy, Netherlands, Poland, Portugal, Slovenia, Slovakia and Spain. The second model (2) is a service-based model, where comprehensive and easily accessible professional care is provided by the state and grown-up children are not or only to a limited extent obliged to provide care for their parents. This is the case in Denmark, Finland, Great Britain, Luxembourg, Norway, Iceland, Sweden and Switzerland. ${ }^{7}$

Last but not least Saraceno and Keck (2010) also offer a care typology for Europe based on childcare as well as on elderly care. For our purpose we only refer to the part which focuses on elderly care. Saraceno and Keck distinguish between three care models (plus a mixed form). The first model (1) is called familialism by default, or unsupported familialism, which means that there are "neither publicly provided alternatives to, nor financial support for family care" (Saraceno and Keck 2010: 676). This model includes Bulgaria, Greece, Italy, Latvia, Poland, Portugal, Slovenia, Slovakia and Spain. The second model (2) is called supported familialism, which means that "policies, usually

\footnotetext{
${ }^{7}$ Haberkern et al. (2012) make the additional point that the share of irregular providers of care (once a month or less often) is much higher in Scandinavian countries while carers in Mediterranean countries tend to have the highest provision of time; in our own analysis with ESS data, we cannot replicate this finding.
} 
through financial transfers, including taxation and paid leaves, support (specific) family members in keeping up their financial and care responsibilities" (Saraceno and Keck 2010: 676). This is the case in the Czech Republic, Estonia, Germany, Great Britain and Hungary. The third model (3) is called de-familialisation, which means that "individualisation of social rights [...] reduces family responsibilities and dependencies" (Saraceno and Keck 2010: 676). This model includes Austria, Belgium, Denmark, France, Ireland, Luxembourg, Netherlands, Norway and Sweden. And finally Saraceno and Keck (2010) suggest that there is a fourth variant (4), it being an option between supported familialism and de-familialisation. Examples are Finland, Iceland and Switzerland.

To test which of the three typologies describes the involvement in informal care of men and women in different European countries best we again used ESS data. We combined two questions relevant for elderly care: (1) Apart from your own children, how often, if at all, do you provide unpaid help to a family member or relative outside your household with childcare, other care, housework or home maintenance? (2) And apart from housework, do you look after others in your household, such as small children or someone ill, disabled or elderly? These questions cover a wide range of productive activities, not just elderly care. ${ }^{8}$ Since it is mainly in Southern European countries in which people live in households with more than two generations (Attias-Donfut et al. 2005) our informal care measure in these countries likely also includes grandchild care. In Northern European countries we likely cover mostly partner care within the household. We however accept this shortcoming in order to be able to cover a wider range of countries as would be possible with the alternative SHARE dataset. Moreover, this allows us to achieve a greater comparability to our analyses on volunteering participation which we present in the following. ${ }^{9}$

The drawback however is that we only have binary information when calculating the weighted country mean in informal caring involvement. We used those means of caring involvement as dependant variable in a regression model, estimating the explanatory power of the caring typologies as shown in Table 4. We found that for women, the typology developed by Saraceno and Keck suits the data best. Of all three typologies, Saraceno and Keck have the lowest AIC (-41.31) and the highest adjusted $\mathrm{R}^{2}(0.36)$. For men, the picture is less clear. But still the typology of Saraceno and Keck is the most suitable since the adjusted $\mathrm{R}^{2}$ is higher $(0.30$ compared to 0.27 and 0.20$)$ and the AIC is lower ( -33.22 compared to -31.51 and -31.66$)$ as with the typologies of Bettio and Plantenga or Haberkern and Szydlik.

This suggests that the most important criteria to classify caring regimes is the role which is attributed to the family in caring for their elderly family members. The way in

\footnotetext{
${ }^{8}$ Although we acknowledge the general issue of cultural comparability of survey questions in comparative studies, we believe that our operationalization of informal care by these two rather concrete questions does not leave too much space for cultural interpretation. Respondents do not have to name these activities "caring" which might indeed be a more sensitive cultural word.

${ }^{9}$ An alternative dataset which contains information on employment, informal caregiving as well as volunteering is the European Quality of Living Survey (EQLS), a representative survey which is done every four years since 2003 by the European Foundation for the Improvement of Living and Working Conditions and which is used by the already mentioned AAI. Although it contains all European Union member states, it excludes countries, such as Norway and Switzerland in the most recent wave (2012). For the purpose of our paper, this causes problems in the second part of our empirical analysis where we test the explanatory power of different welfare state typologies: due to the country selection in the EQLS some classifications contain categories with only one country. Using ESS data with a different country selection ensures that each category contrains at least two countries.
} 
which the welfare state supports families with their caring obligations, i.e. whether the support is state-funded or insurance-based (Bettio and Plantenga 2004) or whether the state provides financial support or elderly homes (Haberkern and Szydlik 2008) does not seem to be as important for understanding differences in European elderly's participation in informal care.

\section{Typologies of Volunteering}

While the large majority of welfare state typologies addressing the importance of other types of unpaid work focus on care work, be it for children or elderly family members, they mostly neglect unpaid work outside the family, namely voluntary engagement. ${ }^{10}$

When it comes to understanding volunteering in different welfare state contexts, two opposed positions are discussed: On the one hand, the crowding out thesis argues that welfare state provision hinders voluntary engagement (Van Oorschot and Arts 2005); on the other hand, the crowding in thesis assumes that welfare state programs offer incentives for volunteering, e.g. by providing required infrastructure for unpaid activities (Hank and Stuck 2008; Motel-Klingebiel et al. 2005). ${ }^{11}$ Several studies are altogether sceptical that the amount of welfare state expenditures is related to variations in the rate of volunteering in a country (Ruiter and De Graaf 2006; Lundström and Svedberg 2003; Musick and Wilson 2008).

One theoretical approach which aims at deriving a more comprehensive typology from this argument is presented by Pichler and Wallace (2007), who identify different social capital regimes based on patterns of formal and informal social capital within a society. The authors combine social network theories (mainly related to informal social capital: social networks and support within the family) with research on democracy and civil society (mainly related to formal social capital: association behaviour) (Pichler and Wallace 2007). Analysing formal social capital in a society, three country clusters can be identified: The first country cluster is formed by the Nordic countries (Denmark, Sweden, Finland) with very high rates of formal social capital. The second cluster contains Western-Central (France, Germany, Belgium, Luxemburg, Netherlands, Austria) and British-Irish countries (Great Britain and Ireland) who are believed to follow the hypothesis of complementarity: formal and informal social capital are similarly strong, leading to moderate rates of formal social capital. The third country cluster includes Eastern-Central (Poland, Czech Republic, Slovakia, Hungary, Slovenia),

\footnotetext{
${ }^{10}$ While it is true that informal care can also be given to non-family members, such as neighbours, previous research shows that the largest share of informal care is given within the family, namely for partners and parents (in law) (Attias-Donfut et al. 2005). On the other hand, volunteering is usually defined by engagement outside the realm of the family (and other close social ties, such as neighbours). Although we acknowledge that the two dimensions of productive ageing are thus closely linked, we believe that it makes sense to differentiate between more family-related informal care and volunteering as an activitiy which is characterised by a person's engagement outside the family.

${ }^{11}$ An assumption reconciling the two positions states that the relation between state and private engagement is context-dependent, i.e. depends on the area of volunteering and the organisational context in which volunteering takes place. Thus, in liberal welfare states, the lack of social services is substituted to a large degree with voluntary engagement in church organisations ("service function"), while social democratic welfare states support especially the (active) membership in trade unions and political organisations (“expressive function”) (Janoski 1998; Salamon and Sokolowski 2003).
} 
Table 4 Explanatory power for welfare typologies on elderly's informal care

\begin{tabular}{lllll}
\hline & & Bettio/ Plantenga & Haberkern/ Szydlik & Saraceno/ Keck \\
\hline \multirow{4}{*}{ Men } & N & 23 & 23 & 23 \\
& Groups & 5 & 2 & 4 \\
& R2 & 0.41 & 0.23 & 0.40 \\
& Adj. R2 & 0.27 & 0.20 & 0.30 \\
\multirow{3}{*}{ Women } & AIC & -31.51 & -31.66 & -33.22 \\
& BIC & -25.83 & -29.39 & -28.68 \\
& R2 & 0.36 & 0.26 & 0.44 \\
& Adj. R2 & 0.22 & 0.22 & 0.36 \\
& AIC & -36.17 & -38.74 & -41.31 \\
& BIC & -30.49 & -36.47 & -36.77 \\
\hline
\end{tabular}

ESS (2004), own calculations (weighted)

Baltic (Estonia, Latvia, Lithuania) and Balkan (Bulgaria, Rumania) countries as well as Southern European countries (Portugal, Spain, Italy, Greece). These countries are believed to follow the hypothesis of substitution: informal social capital replaces formal social capital, leading to low levels of formal social capital.

Musick and Wilson (2008) suggest a somewhat different typology of volunteering clusters based on Esping-Andersen's typology: They differentiate between (1) conservative countries where volunteering is not encouraged by the state which provides few institutional structures for volunteers, (2) countries undergoing the transition to democracy which have few independent voluntary associations and a poorly developed civil society, resulting in low volunteering rates, (3) liberal regimes where volunteering is a substitute for government programs which leads to fairly high volunteering rates, and (4) socialist regimes where volunteering is an adjunct to generous welfare provisions and encourages high volunteering rates (Table 5).

To test which of these two typologies has more explanatory power to describe elderly European's voluntary engagement we use ESS data again. The first wave of the ESS contains a special module about volunteering. People were asked if they have done voluntary work in any of the following fields within the last 12 months: Sports/ outdoor activity club; cultural/hobby activity organisation; trade union; business/profession/farmer organisation; consumer/automobile organisation; humanitarian organisation etc.; environment/peace/animal organisation; religious/church organisation; political party; science/education/teacher organisation; social club etc.; other voluntary organisation. We created a country specific mean containing the share of people who reported that they had been involved in voluntary work in at least one of the mentioned fields within the last 12 months. $^{12}$

Since $85 \%$ of all volunteers report to be involved in one or two activities, this seems a reasonable strategy to us. Although there might be some correlation between reporting

\footnotetext{
${ }^{12}$ We acknoweldge that the ESS, like any other country comparative study is confronted with the challenge of different cultural interpretations of questions. Thus, in countries where helping neighbours is part of "normal" social behaviour, attributing those activities to volunteering may not occur. Since our analysis only deals with formal volunteering, i.e. in organisations, we believe however that the problem is much less of an issue.
} 
Table 5 Classification of welfare typologies on voluntary engagement

\begin{tabular}{|c|c|c|}
\hline & Classification & Country \\
\hline \multirow{3}{*}{$\begin{array}{l}\text { Pichler/ } \\
\text { Wallace } \\
\text { (2007) }\end{array}$} & 1. High formal social capital & $\begin{array}{l}\text { Denmark (29), Finland (14), Sweden (33), } \\
\text { Norway (36) }\end{array}$ \\
\hline & 2. Medium formal social capital & $\begin{array}{l}\text { Austria (14), Belgium (20), France (18), } \\
\text { Germany (26), Great Britain (28), Ireland } \\
\text { (18), Luxembourg (14), Netherlands (35) }\end{array}$ \\
\hline & 3. Low formal social capital & $\begin{array}{l}\text { Greece (6), Hungary (6), Italy (6), Poland } \\
\text { (5), Portugal (5), Slovenia (18), Spain (6) }\end{array}$ \\
\hline \multirow{4}{*}{$\begin{array}{l}\text { Musick/ } \\
\text { Wilson } \\
(\mathbf{2 0 0 8 )}\end{array}$} & 1. Liberal & Great Britain (28), Ireland (18) \\
\hline & 2. Socialist & $\begin{array}{l}\text { Austria (14), Belgium (20), Denmark (29), } \\
\text { Luxembourg (14), Sweden (33), } \\
\text { Netherlands (35), Norway (36) }\end{array}$ \\
\hline & 3. Conservative & $\begin{array}{l}\text { Finland (14), France (18), Germany (26), } \\
\text { Italy (6), Portugal (5), Spain (6), } \\
\text { Greece (6) }\end{array}$ \\
\hline & 4. Transitional Democracies & Hungary (6), Poland (5), Slovenia (18) \\
\hline
\end{tabular}

Remark: Numbers in parentheses indicate the share of volunteers among men and women aged 50 to 75 , for a gender separated overview on the share of volunteers in country see Table A1 in the online appendix

commitments in several organisations and frequency of volunteering, this is certainly not always the case. We then calculated how well the country clusters predict the amount of elderly volunteers in the European countries, respectively for the two typologies.

Our analyses as presented in Table 6 show that the classification of Pichler and Wallace predicts voluntary engagement better than the classification of Musick and Wilson: The AIC is lower for men (-37.64 compared to -33.13$)$ as well as for women ( -48.94 compared to -36.86$)$ and the adjusted $\mathrm{R}^{2}$ is higher for men $(0.45$ compared to 0.34 ) and also for women (0.64 compared to 0.35 ).

We thus conclude that the relation between formal and informal social capital seems to be the driving force in explaining elderly's participation in volunteering activities in a country. In those countries with a high degree of formal social capital - which at the same time have a low degree of informal social capital - elderly's active participation in volunteering associations is highest. This finding again stresses the importance to assess the role of the family in a society: In those countries where informal social capital, namely family networks, plays a major role as is the case in South European (and some East European) countries, the elderly are less engaged in volunteering associations.

\section{Conclusion: Productive Ageing Regimes in Europe}

This article set out to compare productive ageing regimes by assessing the explanatory power of different welfare state typologies which were developed for the general population for elderly's participation in different types of paid and unpaid work in Europe. In the first part of the article, we give an overview on elderly Europeans' participation in paid work, informal care and volunteering, based on previous research. 
Table 6 Explanatory power for welfare typologies on elderly's volunteering

\begin{tabular}{llll}
\hline & & Pichler-Wallace & Musick/ Wilson \\
\hline \multirow{4}{*}{ Men } & G & 19 & 19 \\
& Groups & 3 & 4 \\
& R2 & 0.52 & 0.45 \\
Adj. R2 & 0.45 & 0.34 \\
Women & AIC & -37.64 & -33.13 \\
& BIC & -34.81 & -29.35 \\
R2 & 0.68 & 0.46 \\
Adj. R2 & 0.64 & 0.35 \\
AIC & -48.94 & -36.86 \\
BIC & -46.10 & -33.08 \\
\hline
\end{tabular}

ESS (2002), own calculations (weighted)

Male employment above the age of 50 is high in Scandinavian countries, moderate in conservative countries and relatively low in Mediterranean countries. Similarly, women aged 50 and older have low employment rates, especially in Mediterranean countries. Postcommunist countries are not so easily classified. After the dissolution of the Soviet Union, the formerly communist countries took different paths of restructuring society. The labour force participation of elderly men in post-communist countries is lower than average in Europe with some countries on the very low end (Poland, Hungary, Slovenia) but others above average (Czech Republic). Women in post-communist countries aged between 50 and 54 have rather high employment rates (70-86\%), but apart from Estonia their employment rates drop tremendously in the age group of 60 to 64 year old women (13-20\%).

Participation in informal care work is high in Nordic countries, low in Southern countries and medium in Eastern and Continental Europe. Post-communist countries are on a medium level, they are more often involved in care than Southern Europeans but less often than Scandinavians.

Regarding volunteering, we find a similar picture: High rates are observed in Scandinavian countries (Sweden, Norway and Denmark), as well as in the Netherlands and Great Britain. Low rates are observed in Southern countries (Portugal, Italy, Spain and Greece) and some post-communist countries, like Poland and Hungary.

The main aim of this article was to compare three areas of productive activities and conclude which of the available welfare state typologies best describe the situation of elderly Europeans. Our model comparison suggests that for labour market participation, Esping-Andersen's $(1990,1999)$ extended classification, differentiating according to the degree of de-commodification in a country as well as between familiarised and defamiliarised welfare states has more explanatory power for men as well as for women than Pfau-Effinger's (2005) typology based on cultural models of informal care, which result in different couple strategies. As we pointed out earlier, Pfau-Effinger's typology was designed to describe the labour market participation of parents with young children. Our expectation that the cumulation of advantages and disadvantages over the lifecourse lead to similar patterns for the older population with caring responsibilities does not seem to hold up. Moreover, the importance of culture is not 
operationalized well in our analysis. Both reasons might lead to the finding that the typology does not fit our data of European elderly.

Concerning informal care typologies, our model comparison suggests that it is mainly the role which the welfare state attributes to the family that makes a difference in how involved European elderly are in informal care (Saraceno and Keck 2010). Whether the care is state or insurance financed does not seem to be that decisive (Bettio and Plantenga 2004), neither whether a welfare state provides financial means to the families or invests in elderly homes (Haberkern and Szydlik 2008). However differences in the explanatory power for the different models are small for men which makes the conclusion for them rather tentative.

Regarding volunteering, our model comparison suggests that it is mainly the degree of formal and informal social capital which explains whether elderly European men and women get involved (Pichler and Wallace 2007). We should note however, that the category of liberal countries in Musick and Wilson's (2008) classification consists of only two countries. Although this is common pratice in welfare state research - as for example also in the liberal category of Esping-Andersen's (1990) classical typology - it is unfortunate because it attributes a lot of importance to a single country case. Bearing these shortcomings in mind, we conclude that - similar to the other forms of productive activities - the role of the family in a society seems to be of central importance in determining the elderly's participation.

We thus confirm that productive ageing strategies in Europe roughly follow a northsouth gradient. It is mainly Northern European countries with a high degree of decommodification and de-familialisation which encourage elderly men and women to stay employed while Southern European countries with a low degree of de-commodification and a high degree of familialisation have very low employment rates among the elderly. At the same time, Northern European countries are most successful in encouraging their elderly's informal caring activities while Southern European countries have rather low informal care rates. This seems surprising at first since these countries are characterised by a high degree of de-familialisation. As crowding-in theories suggest however, a welfare state which provides extensive formal care structure and thus leaves very few duties to the family encourages family members to provide additional informal care to their family members. Not least, the role of formal or informal social capital in a country seems to be most important for the elderly's decision to participate in volunteering activities. Again, Nordic countries, which are characterised by a high importance of formal social capital are most successful in encouraging elderly's volunteering activities while Southern European countries with a high importance of informal social capital, namely family networks, have the lowest volunteering rates among the elderly.

The north-south gradient which we observe for all three types of productive ageing activities of elderly Europeans is thus mainly related to the role which welfare states attribute to the family. Welfare states that have a high degree of de-familialisation fare best in encouraging their elderly men and women to participate in all types of paid and unpaid productive activities while welfare states which attribute a high responsibility to the family are least successful in encouraging their elderly to take on employment, informal care or volunteering. This again supports the idea that well developed welfare state provisions tend to "crowd in" more productive activities of the elderly. In Southern Europe, the lack of welfare provision is subsidised by informal help which does not leave much space for additional productive activities: neither do these countries perform very well on women's labour market integration, nor do they succeed 
in supporting elderly's engagement in volunteering organisations. In order to increase the elderly's participation in paid and unpaid productive activities, the Northern European strategy of providing welfare support outside the family seems to be most successful. To what extent it is possible to activate similar potentials in Southern European countries with their high value of family relations is subject to future research and policy developments.

Acknowledgements We kindly thank the participants of the doctoral colloquium in Empirical Social Research at the University of Konstanz, Germany, as well as participants of the RC 28 Summer Meeting 2016 in Bern, Switzerland, for valuable comments. Moreover, we thank the three anonymous reviewers for their helpful comments. European Social Survey data were kindly provided by Norwegian Social Science Data Services.

\section{Compliance with Ethical Standards}

Funding This work was supported by the German Research Foundation (grant no. STR 1322/2-1, AOBJ: 604,774).

\section{References}

Attias-Donfut, C., Ogg, J., \& Wolff, F.-C. (2005). Family support. In A. Börsch-Supan, A. Brugiavini, H. Jürges, J. Mackenbach, J. Siegrist, \& G. Weber (Eds.), Health, ageing and Retirement in Europe. First results from the survey of health, ageing and Retirement in Europe (pp. 171-178). Strauss $\mathrm{GmbH}$ : Mörlenbach.

Bettio, F., \& Plantenga, J. (2004). Comparing care regimes in Europe. Feminist Economics, 10(1), 85-113.

Brandt, M., Haberkern, K., \& Szydlik, M. (2009). Intergenerational help and Care in Europe. European Sociological Review, 25(5), 585-601.

Caro, F. G. (2008). Produktives Altern und ehrenamtliches Engagement in den USA. In M. Erlinghagen \& K. Hank (Eds.), Produktives Altern und informelle Arbeit in modernen Gesellschaften (pp. 75-90). Wiesbaden: VS Verlag.

Crompton, R., \& Lyonette, C. (2006). Work-life 'Balance'in Europe. Acta Sociologica, 49(4), 379-393.

DiPrete, T. A., \& Eirich, G. M. (2006). Cumulative advantage as a mechanism for inequality: A review of theoretical and empirical developments. Annual Review of Sociology, 32, 271-297.

Ehrhardt, J. (2009). Ehrenamt. Formen, Dauer und kulturelle Grundlagen des Engagements. Berlin: Campus.

Erlinghagen, M. (2008). Informelle Arbeit in alternden Gesellschaften-Möglichkeiten und Grenzen des, produktiven Alterns. Schmollers Jahrbuch, 128, 237-259.

Erlinghagen, M., \& Hank, K. (2008). Produktives Altern und informelle Arbeit in modernen Gesellschaften. Wiesbaden: VS-Verlag.

Esping-Andersen, G. (1990). The three worlds of welfare capitalism. Cambridge: Polity Press.

Esping-Andersen, G. (1999). Social foundations of postindustrial economies. Oxford: Oxford University Press.

Haberkern, K., Schmid, T., Neuberger, F., \& Grignon, M. (2012). The role of the elderly as providers and recipients of care. In OECD (Ed.), The future of families to 2030 (pp. 189-257).

Haberkern, K., \& Szydlik, M. (2008). Pflege der Eltern - ein europäischer Vergleich. Kölner Zeitschrift für Soziologie und Sozialpsychologie, 60(1), 78-101.

Hank, K. (2011). Societal determinants of productive Aging: a multilevel analysis across 11 European countries. European Sociological Review, 27(4), 526-541.

Hank, K., \& Erlinghagen, M. (2005). Volunteer work. In A. Börsch-Supan, A. Brugiavini, H. Jürgens, J. Mackenbach, J. Siegrist, \& G. Weber (Eds.), Health, ageing and retirement in Europe. First results from the survey of health, ageing and Retirement in Europe (pp. 259-264). MEA: Mannheim. 
Hank, K., \& Erlinghagen, M. (2010). Volunteering in "old” Europe: patterns, potentials, limitations. Journal of Applied Gerontology, 29, 3-20.

Hank, K., \& Stuck, S. (2008). Gesellschaftliche Determinanten produktiven Alterns in Europa. In A. BörschSupan, K. Hank, H. Jürgens, \& M. Schröder (Eds.), 50plus in Deutschland und Europa-Ergebnisse des Survey of Health, Ageing and Retirement in Europe (pp. 71-93, Produktives Altern und informelle Arbeit in modernen Gesellschaften). Wiesbaden: VS Verlag.

Henz, U. (2009). Couples' provision of informal care for parents and parents-in-law: far from sharing equally? Ageing and Society, 29, 369-395.

Janoski, T. (1998). Citizenship and civil society: A framework of rights and obligations in liberal, traditional, and social democratic regimes. Cambridge: Cambridge University Press.

Kerschen, N. (2009). The welfare system of Luxembourg: from past dependency to the European approach. In K. Schubert, S. Hegelich, \& U. Bazant (Eds.), The handbook of European welfare systems (pp. 310-327). Abingdon: Routledge.

Kotsadam, A. (2011). Does informal eldercare impede women's employment? The case of European welfare states. Feminist Economics, 17(2), 121-144.

Lancee, B., \& Radl, J. (2014). Volunteering over the life course. Social Forces, 93(2), 833-862.

Lewis, J., \& Ostner, I. (1994). Gender and the evolution of European social policy. In Working paper 4 of the Centre for Social Policy Research. Bremen: University of.

Lundström, T., \& Svedberg, L. (2003). The voluntary sector in a social democratic welfare state-the case of Sweden. Journal of Social Policy, 32(2), 217-238.

Mahon, R. (2002). Child care: Toward what kind of "social Europe"? Social Politics, 9(3), 343-379.

Mills, M., \& Blossfeld, H.-P. (2005). Globalization, uncertainty and the early life course. A theoretical framework. In H.-P. Blossfeld, E. Klijzing, M. Mills, \& K. Kurz (Eds.), Globalization, uncertainty and youth in society (pp. 1-24). Abingdon: Routledge.

Mitton, L. (2009). The British welfare system: marketization from Thatcher to new labour. In K. Schubert, S. Hegelich, \& U. Bazant (Eds.), The handbook of European welfare systems. Abingdon: Routledge.

Morel, N. (2007). From subsidiarity to 'free choice': Child- and elder-care policy reforms in France, Belgium, Germany and the Netherlands. Social Policy \& Administration, 41(6), 618-637.

Morrow-Howel, N., Hinterlong, J., \& Sherraden, M. (2001). Productive Aging: Concepts and challenges. Baltimore: John Hopkins University Press.

Motel-Klingebiel, A., Tesch-Römer, C., \& Kondratowitz, H.-J. (2005). Welfare states do not crowd out the family: evidence for mixed responsibility from comparative analyses. Ageing \& Society, 25, 863-882.

Musick, M., \& Wilson, J. (2008). Volunteers: a social profile (Vol. book, whole). Bloomington: Indiana Univ. Press.

OECD (2014). Labour force statistics. Employment Rates 2014. http://stats.oecd.org/OECDStat Metadata/ShowMetadata.ashx?Dataset=LFS_SEXAGE_I_R\&ShowOnWeb=true\&Lang=en. Accessed 12 April 2015.

Olafsdottir, S. (2007). Fundamental causes of health disparities: stratification, the welfare state, and health in the United States and Iceland. Journal of Health and Social Behavior, 48(3), 239-253.

O'Reilly, P., \& Caro, F. G. (1995). Productive Aging. Journal of Aging \& Social Policy, 6(3), 39-71.

Pfau-Effinger, B. (2005). Welfare state policies and the developments of care arrangements. European Societies, 7(2), 321-347.

Pichler, F., \& Wallace, C. (2007). Patterns of formal and informal social Capital in Europe. European Sociological Review, 23(4), 423-435.

Ruiter, S., \& De Graaf, N. D. (2006). National Context, religiosity, and volunteering: results from 53 countries. American Sociological Review, 71(2), 191-210.

Salamon, L. M., \& Sokolowski, S. W. (2003). Institutional roots of volunteering: Toward a macro-stuctural theory of individual voluntary action. In P. Dekker \& L. Halman (Eds.), The values of volunteering. Cross-cultural perspectives (pp. 71-90). New York: Kluwer Academic/Plenum Publishers.

Salamon, L. M., \& Sokolowski, S. W. (2004). Global civil society: Dimensions of the nonprofit sector. Bloomfield: Kumarian Press.

Saraceno, C., \& Keck, W. (2010). Can we identify intergenerational policy regimes in Europe? European Societies, 12, 675-696.

Sarkisian, N., \& Gerstel, N. (2004). Explaining the gender gap in help to parents: The importance of employment. Journal of Marriage and Family, 66(2), 431-451.

Szelewa, D., \& Polakowski, M. P. (2008). Who cares? Changing patterns of childcare in central and Eastern Europe. Journal of European Social Policy, 18(2), 115-131.

Szinovacz, M. E., \& Davey, A. (2008). The division of parent care between spouses. Ageing and Society, 28(4), 571-597. 
Van Oorschot, W., \& Arts, W. (2005). The social capital of European welfare states: The crowding out hypothesis revisited. Journal of European Social Policy, 15(1), 5-26.

Zaidi, A., Gasior, K., Hofmarcher, M. M., Lelkes, O., Marin, B., Rodrigues, R., et al. (2013). Active Ageing Index 2012. Concept, methodology and final results. European Centre Vienna. available at: http://www. euro.centre.org/data/1453740620_84975.pdf. 